\title{
BAKTERI Escherichia coli PADA AIR PENCUCI IKAN DI PASAR BAHU MANADO
}

\author{
Norce Elin Kapisa, Semuel M. Timbowo, Hanny W. Mewengkang \\ Fakultas Perikanan dan Ilmu Kelautan, Universitas Sam Ratulangi, Manado, Sulawesi Utara.
}

\begin{abstract}
ABSTRAK
Air merupakan media pelarut yang penting dalam pencucian ikan, sebab dengan pencucian ikan dapat mengurangi sampai menghilangkan bahan kimia ataupun mikro organisme berbahaya. Dengan mengetahui kualitas air yang digunakan dapat mencegah kontaminasi bakteri patogen berasal dari air terhadap produk oleh konsumen.

Penelitian bertujuan untuk mengenal keberadaan bakteri pada E. coli pada air pencuci ikan di Pasar Tradisional Bahu Manado. Metode yang digunakan dalam penelitian yang dilakukan untuk mengungkapkan keterangan suatu fakta tertentu suatu terperinci dan sistematik. Parameter yang diamati dalam penelitian ini adalah masalah mikrobiologi meliputi bakteri dan total E. coli pada air pencuci ikan. Perlakuan yang diberikan adalah air pencuci ikan dan air pencuci ikan diberi khlorin $10 \%$ total bakteri tertinggi terdapat pada air pencuci ikan tanpa khlorin sebesar 2400. Dan terendah pada air pencuci ikan dengan khlorin $10 \%$ ppm.
\end{abstract}

Kata kunci: Escherichia coli, kualitas air, kontaminasi, pasar tradisional.

\section{PENDAHULUAN}

Air merupakan media pelarut yang penting dalam pencucian ikan, sebab dengan pencucian ikan dapat mengurangi bahan kimia ataupun mikro organisme berbahaya. Untuk mendapat hasil yang diinginkan air yang digunakan dalam pencuci ikan harus memenuhi persyaratan secara mikrobiologis yaitu tidak terdapat mikro organisme mepatogen. Karena itu, penyediaan air bersih yang cukup dan berkualitas menjadi salah satu faktor penentu keberhasilan dalam industri perikanan.

Air tempat yang cocok untuk perkembangbiakan mikroba yang bersifat patogen. Menurut Laksmi (1988) mikroba patogen utama dari air yang berasal dari kotoran manusia diantaranya yaitu, Salmonella, Shigella, Vibrio cholera, dan Escherichia coli. Escherichia coli merupakan bakteri indikator terhadap kontaminasi fases terhadap air.

Pencegahan penurunan mutu ikan dari air yang dipakai adalah dengan cara menggunakan air yang sudah mengalami proses klorinasi. Proses pembersihan air yang biasa dilakukan adalah desinfeksi. Menurut Winarno (1993) air sumur yang terkontaminasi dapat dihilangkan dengan penambahan klorin, sebab senyawa tersebut bila bereaksi dengan air akan mampu membunuh bakteri patogen.

Berdasarkan perhitungan ekonomis, efisiensi dan kemudahan penggunaannya, maka penggunaan klorin merupakan metode yang umum dilakukan. Penelitian ini bertujuan untuk mengetahui total bakteri dan total Escherichia coli pada air pencuci ikan yang diambil dari Pasar Bahu Manado.

\section{METODOLOGI PENELITIAN}

Bahan baku yang dipakai dalam penelitian ini adalah sampel air pencuci ikan, $\mathrm{NaCl} 0,9 \%$, Nutrien Agar (NA), khlorin atau kaporit $\left[\mathrm{Ca}(\mathrm{OCl})_{2}\right]$ Akuades dan ikan yang digunakan dalam pencucian. Alat yang digunakan dalam penelitian ini adalah autoklaf, mikroskop, timbangan, inkubator, lampu spritus, alumunium foil, botol, kapas, tissue, jarum ose, kaca objek, tabung reaksi, cawan petri, tabung durham, pipet ukur, pipet tetes, oven, gelas ukur $\mathrm{pH}$ meter beker glass, ember dan cool box.

Tempat pengambilan Pasar Bahu Kecamatan Malalayang Manado. Selanjutnya sampel dianalisis di laboratorium Mikrobiologi Hasil Perikanan, Program Studi Teknologi Hasil Perikanan, Jurusan Pengolahan Hasil Perikanan, Fakultas Perikanan dan Ilmu Kelautan UNSRAT. Waktu penelitian dimulai dari penyusunan laporan sampai ujian akhir, mulai dari bulan November-Desember 2014.

Pengambilan sampel air pencuci ikan. Sampel dimasukan dalam botol sampel dengan membuka penutup botol dan memasukkan ke dalam air sampai terisi air sebanyak volume botol dan langsung ditutup. Botol yang sudah 
terisi sampel dimasukan dalam cool box yang berisi hancuran es kemudian dibawa ke laboratorium untuk di analisis

Metode penelitian yang digunakan adalah eksploratif yaitu penelitian yang dilakukan untuk mengungkap keterangan suatu fakta secara terperinci dan sistematis Mantjoro dan Manus (1987), Total Plate Count (TPC) adalah perhitungan jumlah bakteri yang bertujuan untuk menentukan secara kuantitatif jumlah koloni bakteri yang tumbuh pada media agar. Prosedur perhitungan jumlah koloni bakteri Menurut Fardiaz (1993) sebagai berikut:

$$
\mathrm{TPC}=\text { Jumlah Koloni } \times \frac{1}{\text { Pengenceran }}
$$

\section{HASIL DAN PEMBAHASAN}

\section{Analisa Total Bakteri}

Pengujian total bakteri menggunakan metode tuag dapat diketahui jumlah tertinggi bakteri pada sampel air pencuci ikan pada sampel $\{A\}$, sedangkan jumlah bakteri terendah pada sampel $\{\mathrm{B}\}$, Data yang didapat, air yang digunakan belum memenuhi Persyaratan untuk digunakan dalam pencucian, sebab dalam sampel air ditemukan adanya bakteri lebih dari $100 \mathrm{sel} / \mathrm{ml}$. Menurut Schlegel dan Schmidt ( 1994), jumlah total bakteri dalam air harus di bawah $100 \mathrm{koloni} / \mathrm{ml}$. Data hasil penelitian jumlah total koloni dapat dilihat pada Tabel $1 \mathrm{di}$ bawah ini.

Tabel 1. Total bakteri TPC dari air pencuci ikan

\begin{tabular}{cc}
\hline Sampel & Total Bakteri \\
\hline $\mathrm{A}$ & $4.7 \times 10^{3}$ \\
$\mathrm{~B}$ & $3.0 \times 10^{3}$ \\
\hline Ket.: A= air pencuci tanpa klorin, B= air pencuci diberi klorin $10 \%$
\end{tabular}

Dari hasil pengujian sampel air pencuci ikan mengandung Khlorin (B) memiliki jumlah bakteri terendah sebesar $3,0 \times 10^{3} \mathrm{Cf} / \mathrm{u}$ sedikit dibandingkan sampel air pencuci ikan tanpa Khlorin (A), sebesar 4,7 x $10^{3} \mathrm{Cf} / \mathrm{u}$. Hal ini menunjukkan peranan khlorin sebagai desinfektan untuk air. Dari data yang didapat terlihat bahwa khlorin mampu menekan pertumbuhan bakteri, walaupun jumlah bakteri yang ditemukan masih ada. Menurut Buckle et al (1987), sasaran khlorinasi terdapat air adalah penghancuran bakteri melalui daya germisidal dari khlorin terdapat air.

\section{Analisa Total Kolifrom}

Pengujian total kolifrom menggunkan metode MPN dengan metode EC medium.
Media EC medium menunjukkan pada tabung positif adalah bakteri kolifrom yang menghasilkan asam dan gas dalam tabung durham. Hal ini dapat dilihat pada Tabel 2 di bawah ini.

Tabel 2. Total $E$. coli pada air pencuci ikan.

\begin{tabular}{ccccc}
\hline \multirow{2}{*}{ Sampel } & \multicolumn{3}{c}{$\begin{array}{c}\text { Jumlah Tabung } \\
\text { Yang Positif }\end{array}$} & \multirow{2}{*}{$\begin{array}{c}\text { Total } \\
\text { (MPN / 100 ml) }\end{array}$} \\
\cline { 2 - 4 } & $\mathbf{1 0}^{-\mathbf{1}}$ & $\mathbf{1 0}^{-2}$ & $\mathbf{1 0}^{-\mathbf{3}}$ & \\
$\mathrm{A}$ & 3 & 3 & 3 & $>2.400$ \\
$\mathrm{~B}$ & 3 & 3 & 0 & 240 \\
\hline
\end{tabular}

Ket. $\mathrm{A}=$ Air pecuci tanpa klorin, $\mathrm{B}=$ Air pencuci diberi klorin 10

Hasil pengamatan pada media EC medium menunjukkan pertumbuhan E. coli paling banyak terdapat pada sampel (A), sedangkan sampel (B) sebesar 240.

Tingginya kolifrom pada sampel (A) air tanpa mengandung klorin kemungkinan berasal dari bahan baku ikan yang digunakan dalam pencucian, peralatan atau pekerja yang tidak memperhatikan sanitasi selama dalam pekerjaan. Disamping itu kemungkinan berasal dari air sungai yang digunakan sebagai sumber air pencuci karena di sekitar terdapat kawasan pemukiman masyarakat dimana sungai menjadi tempat pembuangan tinja. Hal ini merupakan sumber kontaminasi E. coli.

Pada air pencuci ikan tanpa klorin (A) memiliki jumlah bakteri E. coli yang lebih tinggi sebesar $>2400$ klorin 240, keberadaan E. coli pada sampel memberikan informasi tentang kontaminasi terhadap air yang dipakai. Menurut winarno dan Fardiaz (1974), bahwa bakteri E. coli yang menfermentasikan laktosa dan membentuk asam dan gas dalam media EC medium. Hasil pengujian E. coli pada EC medium E. coli dapat dilihat pada Gambar 1 di bawah ini.

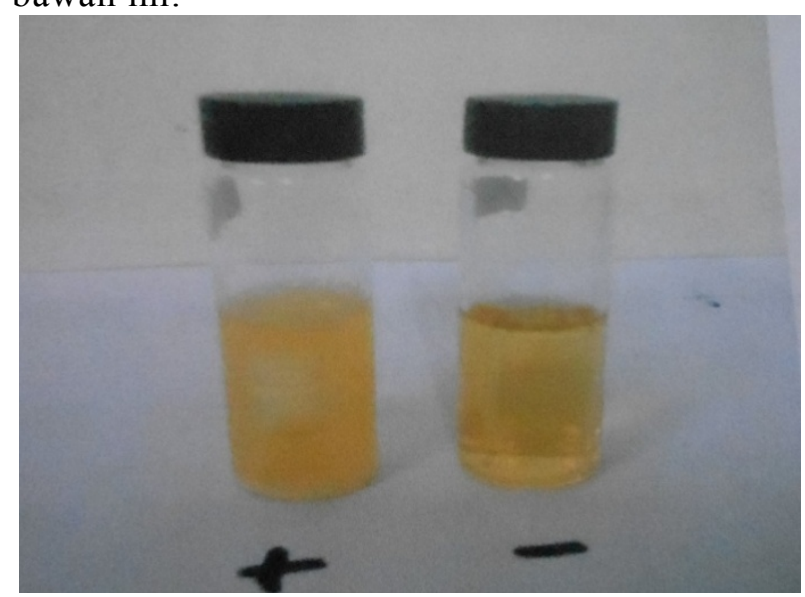

Gambar 1. Media EC medium sampel air. $(+=$ Reaksi Positif, - = Reaksi Negatif ) 
Penambahan klorin pada air pencuci ikan dapat mengurangi pertumbuhan E. coli. Adanya bakteri E. coli dapat memberikan informasi tentang kualitas air yang dipakai belum memenuhi persyaratan secara mikrobiologis, sebagai air pencuci. Secara mikrobiologis persyaratan air pencuci ikan harus memenuhi persyaratan air minum. Kandungan E. coli dalam air minum Menurut WHO ( 1968 ), adalah 1/ $100 \mathrm{ml}$ dan jumlah khlorin diberikan air 1 ppm Suriawiria ( 1986 ). Menurut Schlegel dan Schmidt (1994) bukti keberadaan E. coli dalam air menunjukkan air terkontaminasi oleh bakteri khusus sebagai sumber penyebab penyakit yang harus diambil tindakan pencegahan.

Escherichia coli yang tumbuh pada media yang mengandung klorin, harus berusaha beradaptasi dengan lingkungan tersebut E. coli yang tumbuh pada media $10 \mathrm{ppm}$ klorin tidak mengalami pertumbuhan E. coli tidak mampu beradaptasi dengan baik karena pengaruh klorin. Semakin tinggi klorin yang diberikan semakin lama E. coli beradaptasi dan semakin lama pula pertumbuhan.

Dengan konsentrasi 1-4 ppm belum bisa membunuh dengan efektif .E. coli hanya mampu menekan pertumbuhannya sehingga sasaran klorin untuk pembasmi bakteri patogen tidak tercapai E. Coli yang mampu bertahan hidup akibat pengaruh klorin, akan kembali tumbuh normal sampai pertumbuhan optimum dan mengalami tahap kematian.

Kontaminasi E .coli kemungkinan berasal dari air sungai yang digunakan, pedagang yang tidak memperhatikan kesehatan dan kebersihan pribadi, alat yang dipakai, ikan sebagai bahan jualan, wadah pencuci, saluran air atau lingkungan tempat pencucian. Oleh sebab itu perlu pengendalian terhadap faktor- faktor kontaminasi di atas dengan cara meningkatkan pengawasan mutu terutama sanitasi dan hygiene selama pencucian ikan.

\section{KESIMPULAN}

Total bakteri pada air pencuci ikan lebih rendah $3.0 \times 10^{3}$ yang diberi khlorin dibandingkan dengan air pencuci ikan tanpa pemberian khlorin sebesar $4,7 \times 10^{3} \mathrm{CF} / \mathrm{u}$ Total E. coli pada air pencuci ikan dengan diberi khlorin lebih rendah sebesar 2,4 dibandingkan dengan air pencuci ikan khlorin sebesar $>2400$.

\section{DAFTAR PUSTAKA}

Buckle, K. A. Edwards, R. A. Fleet, G. H, Wooton, M. 1987. Ilmu Pangan. Penerjemah :Hari Adiono. Penerbit Universitas Indonesia. Jakarta

Fardiaz, S, 1982. Mikrobiologi Pangan. Penuntun Praktek Laboratorium. Jurusan Ilmu Dan Teknologi Pangan. Fakultas Pertanian. IPB.Bogor.

Mantjoro, M. E. Manus, O, 1987. Pengantar Kuliah Filsafat Ilmu. Fakultas Perikanan. UNSRAT.

Laksmi, B, J, 1988. Sanitasi Dalam Industri Pangan. Penerbit Komisius jasama Dengan Pusat Antar Universitas Pangan Dan Gisi, IPB. Bogor.

Fardiaz, 1993. Pangan, Gizi, Teknologi Dan Konsumen. PT Gramedia Pustaka Utama. Jakarta.

Suriawira, U. 1986, Mikrobiolgi Pangan Air. Penerbit Alumi Bandung.

Schlegel dan Schmidt, 1994, Mikrobiologi Umum Terjemahan Prof.

Winarno, 1993. Pangan Gizi, Teknologi dan kosumen. PT Gramedia Utama Pustaka Utama Jakarta.

Winarno, F.G. Fardiaz, S, Fardiaz, D, 1974. Air untuk Industri. Departemen Teknologi Hasil pertanian. Bogor.

WHO, 1968, Bentuk undang undang ( UUD ), Oleh PRESIDEN REPUBLIK INDONESIA Nomor : 10 . 